\title{
PERSEPSI MAHASISWA TERHADAP PEMBELAJARAN DALAM JARINGAN UNTUK MATA KULIAH KALKULUS
}

\section{STUDENT PERCEPTION OF CALCULUS DURING ONLINE LEARNING}

\author{
Adelia Alfama Zamista1 ${ }^{*}$, Hanifatul Rahmi ${ }^{2}$, Ari Sellyana ${ }^{3}$, Welly Desriyati ${ }^{4}$ \\ ${ }^{12}$ Teknik Industri, Sekolah Tinggi Teknologi Dumai, Jalan Utama Karya Bukit Batrem II Dumai, \\ 28811, Indonesia \\ 3,4 Teknik Informatika, Sekolah Tinggi Teknologi Dumai, Jalan Utama Karya Bukit Batrem II \\ Dumai, 28811, Indonesia \\ *E-mail: alfadelia17@gmail.com
}

Hp: 085271375657

\begin{abstract}
ABSTRAK
Kalkulus yang merupakan cabang dari matematika merupakan salah satu mata kuliah wajib untuk mahasiswa tingkat awal di STT Dumai. Berdasarkan studi pendahuluan diketahui bahwa sebagian besar mahasiswa menyatakan kalkulus adalah mata kuliah yang sulit dipahami (54\%). Sementara itu di masa pandemi covid-19 ini pola pembelajaran diubah dari yang awalnya tatap muka menjadi pembelajaran dalam jaringan (daring). Perubahan pola pembelajaran ini bisa jadi potensi masalah baru. Oleh karena itu perlu dilakukan penelitian tentang persepsi mahasiswa terhadap pembelajaran daring untuk mata kuliah kalkulus. Tujuan dari penelitian ini adalah melihat kecenderungan persepsi mahasiswa terhadap pelaksanaan perkuliahan kalkulus secara daring. Dengan mengetahui kecenderungan persepsi mahasiswa dapat dilakukan berbagai tindakan untuk meningkatkan kualitas pembelajaran. Penelitian ini merupakan penelitian deskriptif dengan teknik pengumpulan data menggunakan kuesioner online. Hasil penelitian menunjukkan bahwa mahasiswa memiliki persepsi negatif terhadap pembelajaran daring untuk mata kuliah kalkulus, baik dari segi isi materi (89,3\%), interaksi $(79 \%)$ dan lingkungan belajar (50\%). Mahasiswa tetap berpendapat untuk mata kuliah kalkulus proses belajar dengan tatap muka dan mendapat penjelasan langsung dari dosen lebih efektif.
\end{abstract}

Kata kunci: kalkulus, pembelajaran dalam jaringan, persepsi, interaksi pembelajaran

\section{ABSTRACT}

Calculus which is a branch of mathematics is one of the compulsory courses for first year students at STT Dumai. Based on preliminary studies, it is known that most of the students stated that calculus was a difficult subject to understand (54\%). Meanwhile, during the Covid19 pandemic, learning process were changed from initially face-to-face to online learning. This change in learning process could be a new problem. Therefore it is necessary to conduct research to know students' perceptions of online learning for calculus course by knowing the tendency of students' perceptions can be done various actions to improve the quality of learning. This research is a descriptive study with data collection techniques using an online questionnaire. The results showed that students had negative perceptions of online learning for calculus courses, both in terms of content $(89,3 \%)$, interaction $(79 \%)$, and learning environment $(50 \%)$. Students continue to argue that face to face learning process is more effective than online learning.

Keywords: Calculus, online learning, perception, learning interaction 


\section{PENDAHULUAN}

Matematika merupakan salah satu disiplin ilmu yang sering disebut sebagai mother of science, karena matematika merupakan ilmu tentang berbagai pola dan logika yang dapat menjadi dasar untuk pengembangan ilmu lainnya. Hal ini menjadikan matematika sebagai salah satu mata pelajaran wajib bagi sekolah formal untuk kurikulum di berbagai negara [1]. Begitu pula dengan Indonesia yang menjadikan matematika sebagai mata pelajaran wajib dari jenjang sekolah dasar hingga perguruan tinggi.

Sebagai dasar pengembangan berbagai ilmu lainnya, Hudoyo menyatakan bahwa pemfokusan pelaksanaan pembelajaran matematika merupakan keharusan [2]. Sehingga mutlak diperlukan tenaga pengajar matematika yang terampil, dan usaha kontinu untuk meminimalisir kendalakendala dalam pembelajaran matematika.

Salah satu kendala dalam pembelajaran matematika adalah adanya kecemasan pelajar terhadap matematika. Salah satu penyebab kecemasan pelajar terhadap matematika adalah pengalaman belajar yang diterima di masa lampau [2]. Dapat disimpulkan bahwa matematika menjadi momok bagi sebagian besar pelajar karena persepsi negatif pelajar terhadap matematika itu sendiri.

Kini dimasa pandemi covid-19, pembelajaran matematika yang memang sudah dianggap sulit oleh sebagian besar mahasiswa itu dihadapkan dengan potensi kendala baru, yakni berubahnya pola pelaksanaan pembelajaran yang semula dengan tatap muka menjadi pembelajaran dalam jaringan (daring). Hal ini merupakan kebijakan pemerintah Indonesia dalam upaya mengendalikan penyebaran covid-19.
Pembelajaran daring adalah proses pembelajaran yang tidak memerlukan tatap muka langsung antara dosen dan mahasiswa melainkan memanfaatkan jaringan internet dan berbantuan berbagai aplikasi yang mendukung proses pembelajaran [3]. Saifuddin menyatakan pembelajaran daring merupakan salah satu bentuk pemanfaatan internet yang dapat meningkatkan peran mahasiswa dalam pembelajaran [4].

Pembelajaran matematika dengan tatap muka saja sudah mengalami berbagai kendala, kesulitan, dan adanya kemungkinan kecemasan pada mahasiswa yang dibuktikan dengan adanya berbagai penelitian tentang kesulitan belajar matematika, dan kecemasan matematika [5, 6, 7]. Apalagi jika pola pembelajaran diubah dari yang biasa dilakukan menjadi daring. Oleh karena itu perlu dilakukan penelitian untuk melihat persepsi mahasiswa terhadap pembelajaran daring khususnya untuk mata kuliah kalkulus (Kalkulus merupakan cabang ilmu matematika yang mencakup limit, turunan, integral dan deret tak hingga. Mata kuliah matematika di STT Dumai untuk semester genap ini adalah Kalkulus II).

Tujuan dari penelitian ini adalah melihat kecenderungan persepsi mahasiswa terhadap pelaksanaan perkuliahan kalkulus secara daring. Dengan mengetahui kecenderungan persepsi mahasiswa dapat dilakukan berbagai tindakan untuk meningkatkan kualitas pembelajaran.

\section{METODE PENELITIAN}

Penelitian ini merupakan penelitian deskriptif yang dilakukan dengan survei terhadap mahasiswa STT Dumai. Teknik pengumpulan data menggunakan kuesioner online yang dapat diisi oleh mahasiswa pada laman 
https://bit.ly/KuesionerPersepsiMhsS TTD.

Populasi penelitian ini adalah mahasiswa aktif STT Dumai yang berjumlah 895 orang, berdasarkan rumus Slovin dengan toleransi $5 \%$ jumlah sampel 94 orang saja sudah memenuhi, namun saat penyebaran kuesinor secara online 394 mahasiswa memberikan respon terhadap kuesioner. Pada akhirnya seluruh data isian kuesioner dianalisis karena memenuhi jumlah sampel yang dibutuhkan. Sampel diambil dengan teknik simple random sampling dengan asumsi kondisi dan kesiapan mahasiswa STT Dumai mengikuti perkuliahan daring adalah homogen karena seluruh mahasiswa baru pertama kali melaksanakan perkuliahan full daring [5].

Tahapan yang dilakukan dalam penelitian adalah:

a. Penyusunan instrumen penelitian

b. Uji validitas instrumen

c. Perbaikan instrumen setelah validasi

d. Mengumpulkan data

e. Melakukan analisis deskriptif terhadap data yang telah terkumpul

Kuesioner sebagai instrumen penelitian memuat daftar pertanyaan yang berkaitan dengan persepsi mahasiswa terhadap pembelajaran daring untuk mata kuliah kalkulus.

Salah satu fokus pada kuesioner adalah menggali kesulitan mahasiswa dalam mempelajari kalkulus yang indikatornya mengadaptasi karakteristik kesulitan belajar siswa oleh Wood [8].

Pada artikel ini persepsi yang akan dibahas khusus mengenai persepsi mahasiswa terhadap materi pembelajaran kalkulus, pola interaksi, dan lingkungan belajar selama pembelajaran daring.

Instrumen dibuat dengan memanfaatkan google form. Setelah disusun dilakukan uji validitas konstruk terhadap instrumen, yang dilakukan oleh satu orang dosen Bahasa Indonesia dan 10 orang mahasiswa untuk menguji dan mengecek isi instrumen serta keterbacaannya. Hasil uji validitas konstruk oleh dosen Bahasa menyatakan isi instrumen sudah sesuai dengan tujuan penelitian yang akan dicapai, namun ada beberapa tata tulis yang perlu diperbaiki.

Setelah mendapat masukan dari validator, instrumen disempurnakan. Kemudian dilakukan pengambilan data. Karena saat melakukan penelitian dalam situasi pandemi covid-19 maka penyebaran kuesioner juga dilakukan secara daring.

\section{HASIL DAN PEMBAHASAN}

Jalaludin memaparkan bahwa persepsi adalah pengalaman tentang objek, peristiwa, atau hubunganhubungan yang diperoleh dengan menyimpulkan informasi dan menafsirkan pesan [9]. Hal ini senada dengan yang disampaikan oleh Keraf bahwa persepsi adalah proses dimana individu menafsirkan dan mengorganisasikan pola stimulus dalam lingkungan [10]. Dapat disimpulkan bahwa persepsi adalah penafsiran yang diberikan oleh individu terhadap stimulus yang diterimanya. Stimulus dapat berupa objek maupun peristiwa yang diterima oleh indra manusia ataupun dirasakan oleh perasaan. 
Walgito dalam Siregar menyatakan penafsiran terhadap stimulus-stimulus yang diterima sangat dipengaruhi oleh faktor internal individu dan keadaan objek sebagai sumber stimulus (yang akan dipersepsi). Faktor internal individu meliputi pikiran, perasaan, sudut pandang, pengalaman, daya tangkap, harapan, taraf kecerdasan, serta harapan dan dugaan individu sebagai perseptor. Keadaan objek yang dipersepsi merupakan karakteristikkarakteristik yang ditampilkan oleh objek, baik bersifat psikis, fisik, ataupun suasana [11].

Persepsi dapat diklasifikasikan menjadi dua yaitu persepsi positif dan persepsi negatif. Persepsi positif merupakan penilaian individu terhadap suatu objek atau informasi dengan pandangan yang positif atau sesuai dengan yang diharapkan dari objek yang dipersepsikan atau dari aturan yang ada. Sedangkan, persepsi negatif merupakan persepsi individu terhadap objek atau informasi tertentu dengan pandangan yang negatif, berlawanan dengan yang diharapkan dari objek yang dipersepsikan atau dari aturan yang ada [12].

$\begin{array}{ccc}\text { Hasil } & \text { penelitian } & \text { Mulyana } \\ \text { menunjukkan } & \text { bahwa } & \text { terdapat }\end{array}$
hubungan yang positif antara persepsi tentang pembelajaran dengan hasil belajar [13]. Untuk itu perlu diketahui bagaimana persepsi mahasiswa STT terhadap pelaksanaan daring khususnya untuk mata kuliah kalkulus yang kemudian akan digunakan sebagai acuan dalam pelaksanaan pembelajaran berikutnya demi menjaga pencapaian hasil belajar mahasiswa.

Ada tiga aspek yang umum menjadi perhatian dalam pelaksanaan pembelajaran daring, yaitu: materi ajar, interaksi belajar, dan lingkungan belajar $[14,15,16]$.

\section{Persepsi terhadap Materi Ajar}

Materi ajar adalah materi yang harus disampaikan kepada pembelajar (mahasiswa) yang di dalamnya memuat konsep-konsep, teori, atau hukum yang mengantarkan pada tercapainya tujuan pembelajaran. Saat perkuliahan daring penyajian materi ajar tentu tidak dapat disajikan langsung dengan metode ceramah kepada mahasiswa, sehingga dosen perlu menyiapkan bahan ajar yang kemudian harus dibagikan kepada mahasiswa melalui internet.

Prastowo menyatakan bahan ajar merupakan segala bahan (baik informasi, alat, maupun teks) yang disusun secara sistematis, yang menampilkan sosok utuh dari kompetensi yang akan dikuasai siswa dan digunakan dalam proses pembelajaran dengan tujuan perencanaan dan penelaahan implementasi pembelajaran [17]. Persepsi mahasiswa mengenai kualitas penyajian materi ajar baik berupa modul, slide power point, info grafis, gambar, animasi dan video oleh dosen diperlihatkan pada gambar 5 .

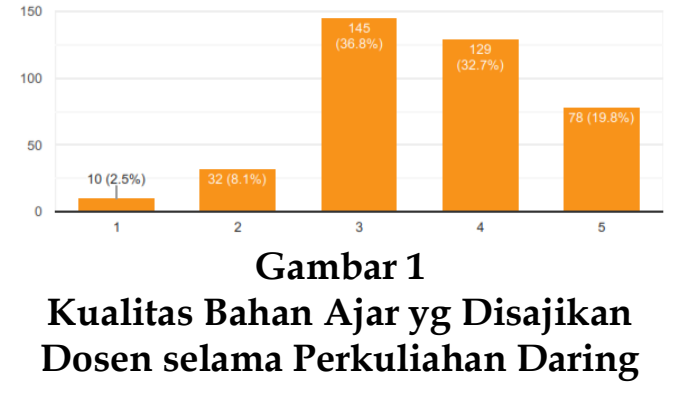

Jawaban dari kuesioner menunjukkan secara umum dosen sudah menyajikan bahan ajar yang baik selama perkuliahan daring. Sedikit keluhan mahasiswa hanya tentang penyajian video yang terkadang diambil dari youtube bukan merupakan video yang dibuat sendiri oleh dosen. Disimpulkan bahwa 89,3\% mahasiswa berpersepsi positif terhadap 
bahan ajar yang disajikan dosen selama perkuliahan daring.

Namun penyajian bahan ajar yang berada pada kategori cukup baik dan baik ini tidak sejalan dengan pemahaman mahasiswa terhadap materi yang diajarkan. Mayoritas mahasiswa tetap merasa kesulitan dalam memahami materi melalui penyajian bahan ajar tanpa adanya tatap muka khususnya materi untuk mata kuliah kalkulus. Salah satu respon mahasiswa tentang penyajian materi ajar yaitu:

"Bagi mahasiswa pembelajaran daring lewat teknologi informasi sebenarnya santai karena cuma dirumah aja dan ga ke kampus. Tetapi sulit bagi saya untuk memahami materi tersebut lebih dalam karena tidak dijelaskan secara langsung oleh dosen kayak langsung bertatapan muka dikampus, apa lagi pelajaran tentang hitungan sudah pasti saya akan agak lama memahami materi tersebut karena hitungan harus dijelaskan langsung tatap muka oleh dosen biar mahasiswa paham"

Terlihat bahwa untuk mata kuliah kalkulus yang memuat materi tentang hitungan mahasiswa merasa kesulitan untuk memahami materi jika pembelajaran dilakukan secara daring.

Ditilik lebih jauh mengenai materi yang dipelajari mahasiswa selama dua bulan dengan sistem daring adalah turunan dan integral (aturan pencarian turunan, telaah integral lipat dua pada persegi panjang, menghitung integral lipat dua sebagai integral berulang dan integral lipat tiga). Khusus untuk materi-materi yang dipelajari selama daring ini kesulitan terbanyak yang dialami mahasiswa berdasarkan isian kuesioner secara berurutan adalah:
1) Lemahnya
kemampuan
mengidentifikasi
serta
memanfaatkan algoritma dalam

memecahkan soal-soal

matematika (57\%).

2) Tidak sanggup mengingat dalildalil matematika (48\%)

3) Tidak mengerti perbedaan posisi dan ukuran angka yang ternyata berpengaruh terhadap makna dan fungsi angka tersebut (30\%)

4) Kesulitan membedakan simbolsimbol dan/atau tidak memahami simbol-simbol matematika (13\%)

5) Lainnya

Kesulitan-kesulitan belajar tersebut membuat mahasiswa berpersepi negatif terhadap materi ajar kalkulus.

Maka untuk mata kuliah kalkulus ternyata persepsi yang positif terhadap bahan ajar belum tentu berkorelasi positif dengan persepsi terhadap isi materi ajar itu sendiri. Persepsi negatif terhadap materi ajar kalkulus tetap membuat mahasiswa sulit memahami materi ajar.

\section{Persepsi terhadap Interaksi Belajar}

Interaksi belajar meliputi interaksi antara mahasiswa dengan dosen dan interaksi antar mahasiswa. Interaksi belajar yang baik mendukung tercapainya hasil belajar yang baik.

Hasil penelitian menunjukkan bahwa interaksi antara dosen dengan mahasiswa dan interaksi antar sesama mahasiswa hanya pada kategori cukup (42\% dan 41\%). Berikut beberapa respon mahasiswa mengenai pola interaksi saat pembelajaran daring:

- Dengan belajar daring lebih berani bertanya dan mengajak diskusi

- Dengan daring jika ingin bertanya bisa langsung bertanya karena dosen sering membuka sesi tanya jawab

- Karna menurut saya metode pembelajaran daring agak sedikit sulit karna tidak melihat penjelasan secara 
langsung dan susah bertanya jika tidak paham

- $\quad$ Metode pembelajaran daring kurang efektif, dimarenakan mahasiswa tidak bebas bertanya kepada dosen,

- Daring membuat mahasiswa dan dosen lebih kreatif, namun komunikasi tidak berjalan lancar

Walaupun ada mahasiswa yang menyatakan dengan pembelajaran daring membuat lebih berani untuk bertanya kepada dosen, namun juga terdapat mahasiswa yang menyatakan dengan daring komunikasi dengan dosen menjadi sulit. Sedangkan untuk interaksi antar mahasiswa hampir tidak ada perbedaan antara kuliah tatap muka dengan kuliah daring.

Setelah ditelusuri penyebab interaksi dengan dosen terasa lebih sulit karena sebagian besar mahasiswa tidak terbiasa bertanya dalam bentuk tulisan. Mahasiswa terbiasa menyuarakan pertanyaan langsung saat tatap muka. Maka interaksi belajar saat perkuliahan daring yang menggunakan aplikasi video seperti zoom dan google meet tidak mengalami masalah yang sama saat pembelajaran daring dengan aplikasi berbagi materi seperti dengan menggunakan google classroom.

Sedangkan dari sisi dosen, menurut mahasiswa umumnya dosen tetap memberikan respon/umpan balik yang cepat saat pembelajaran daring, seperti diperlihatkan pada Gambar 6. Hal ini berarti dosen tetap memberikan jawaban atas pertanyaan dan merespon pendapat siswa dengan cepat meskipun pembelajaran tidak dilakukan secara tatap muka.

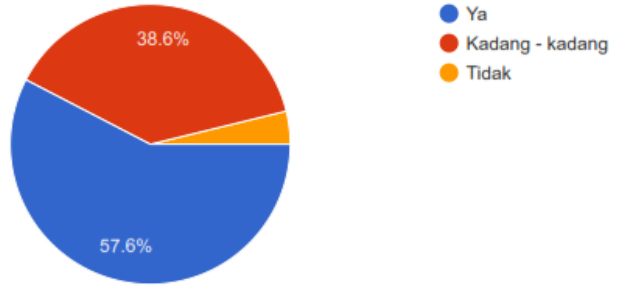

Gambar 2

\section{Dosen Memberikan Respon/Umpan Balik yang Cepat saat Perkuliahan Daring Berlangsung}

Hal lain yang berkaiatan dengan persepsi terhadap interaksi adalah penugasan. Pemberian tugas adalah salah satu bentuk interaksi dosen dan mahasiswa. Adapun persepsi mahasiswa tentang tugas-tugas yang diberikan selama pembelajaran daring yaitu mahasiswa merasa tidak dapat mengerjakan tugas dengan baik $(79 \%)$. Hal ini disebabkan selama pembelajaran daring pembahasan contoh soal sangat terbatas, jikapun ada dalam bentuk modul atau catatan dari dosen yang untuk memahaminya perlu usaha yang lebih. Ditambah lagi tumpang tindihnya tugas antara satu dosen dengan dosen yang lain, sehinga mahasiswa menerima banyak tugas dalam satu hari menyebabkan waktu pengerjaan tugas sangat singkat.

Persepsi negatif terhadap penugasan ini menjadi salah satu kendala dalam pola interaksi selama pembelajaran kalukulus secara daring.

3. Persepsi terhadap Lingkungan Belajar

Lingkungan belajar yang baik adalah lingkungan yang mampu menciptakan ketenangan serta dapat memotivasi untuk belajar lebih baik [19].

Isian kuesinoner menunjukkan bahwa meskipun mahasiswa merasa 
pembelajaran daring lebih fleksibel karena dapat dilakukan dimana saja dan tanpa perlu persiapan seperti mandi dan berdandan untuk ke kampus, namun lingkungan belajar di rumah kurang kondusif untuk perkuliahan. Beberapa pernyataan mahasiswa terkait lingkungan belajar selama pembelajaran daring adalah:

- Konsentrasi belajar terganggu oleh suasana rumah yang ramai.

- Di rumah kadang sulit untuk menolak permintaan orang tua untuk membantu padahal sedang ada kuliah online sehingga tidak konsentrasi

- untuk mahasiswa teknik sekarang tidak efisien dalam daring ini karena adanya kuliah praktek, dalam daring praktek sangat tidak efisien, alangkah baiknya praktek bisa dilakukan secara langsung dari pada daring

Respon-respon mahasiswa diatas memperlihatkan pembelajaran daring yang dilakukan dari rumah dapat mengganggu konsentrasi apalagi kalkulus merupakan mata kuliah yang butuh konsentrasi tinggi saat mempelajarinya. Maka hasil penelitian menunjukkan bahwa mahasiswa memiliki persepsi yang negatif terhadap lingkungan belajar saat diterapkannya pembelajaran daring.

Mahasiswa merasa kondisi belajar di kelas lebih baik. Suasana belajar dikelas juga bisa memotivasi mahasiswa. Seseorang di dalam kelas akan memiliki semangat yang lebih baik bila ia memiliki teman-teman yang giat dalam belajar [16]

\section{KESIMPULAN}

Mayoritas mahasiswa (89,3\%) memiliki persepsi yang positif terhadap penyajian bahan ajar kalkulus oleh dosen namun bahan ajar yang menarik tidak dapat mengubah persepsi negatif mahasiswa terhadap materi kalkulus itu sendiri. Persepsi negatif terhadap materi kalkulus disebabkan berbagai kesulitan yang dialami mahasiswa saat belajar kalkulus.

Untuk aspek interakasi belajar khususnya tentang penugasan $79 \%$ mahasiswa memiliki persepsi negatif. Hal ini dikarenakan untuk menyelesaikan soal-soal kalkulus perlu memahami berbagai contoh soal yang dalam pembelajaran daring ini tidak terlaksana.

Sebagian mahasiswa (50\%) juga memiliki persepsi negatif terhadap lingkungan belajar selama pembelajaran daring mata kuliah kalkulus.

\section{SARAN}

Penelitian ini belum menguji korelasi antara persepsi mahasiswa terhadap pembelajaran daring dengan hasil belajar mahasiswa. Oleh karena itu butuh penelitian lebih lanjut.

\section{DAFTAR PUSTAKA}

[1] Chiu, M. S., et all. (2007). Mathematics as MotheR/Basic of Science in a Analysis of TIMSS 2003 Data. Proceedings og the 31st Conference of the International Group for the Psychology of MATHEMATICS Education, Vol 2. Pp. 145-152. Seoul:PME

[2] Nawangsari, N. A. F. (2001). Pengaruh Self-efficacy dan Expectaci-value terhadap Kecemasan menghadapi Pelajaran Matematika. Jurnal Psikologi Pendidikan. Vol 3(2). Hal: 75-88.

[3] Bentley, Y., Selassie, H., \& Shegunshi, A. (2012). Design and Evaluation of Student-focused e- 
Jurnal THEOREMS (The Original Research of Mathematics) Vol.5 No.1 , Juli. hal. 41-48

URL: http://jurnal.unma.ac.id/index.php/th

Naskah masuk:2020-06-09 Naskah diperbaiki:2020-06-16 Naskah diterima:2020-06-19

learning. Elcetronic Journal of ELearning. $\quad 10(1)$, 1-12. https://doi.org/10.1007/s1064801 3-9243-1.

[4] Zhafira. N. H., Ertika. Y., dan Chairiyaton. (2020). Persepsi Mahasiswa terhadap Perkuliahan Daring sebagai Sarana Pembelajaran Selama Masa Karantina Covid-19. Jurnal Bisnis dan Kajian Strategi Manajemen. Vol. 4 (1), hal: 37-45, ISSN: 2614-2147.

[5] Mutakin. (2013). Analisis Kesulitan Belajar Kalkulus 1 Mahasiswa Teknik Informatika. Junral Formatif. Vol 3 (1). Hal: 49-60. ISSN: 2088$351 X$

[6] Yeni, A. M. (2015). Kesulitan Belajar Matematika di Sekolah Dasar. JUPENDAS. Vol. 2 (2). Hal: 1-10. ISSN:2355-3650.

[7] Saputra. (2014). Kecemasan Matematika dan Cara Menguranginya. PYTHAGORAS. Vol. 3 (2). Hal: 75-84. ISSN: 23015314

[8] Untari, E. (2013). Diagnosis Kesulitan Belajar Pokok Bahasan Pecahan pada Siswa Kelas V Sekolah Dasar. Jurnal Ilmiah STKIP Ngawi. Vol 13 (1). Hal: 1-8

[9] Jalaludin. R. (1998). Pembinaan Kemampuan. Jakarta: Erlangga.

[10] Keraf. G. (2004). Argumentasi dan Narasi. Jakarta: Gramedia Pustaka Utama.

[11] Siregar. N. S. S. (2013). Persepsi Orang Tua terhadap Pentingnya Pendidikan bagi Anak. Jurnal Ilmu Pemerintahan dan Sosial Politik UMA. Vol 1(1) 2013, hal: 11-27. p-ISSN: 2549-1660

[12] Robbins. P. S. (2002). Prinsipprinsip Perilaku Organisasi. Edisi Kelima Diterjemahkan oleh Halida, S.E dan Dewi Sartika, S.S. Jakarta: Erlangga.
[13] Mulyana, A., Hidayat. S., Sholih. (2013). Hubungan antara Persepsi, Minat, dan Sikap Siswa dengan Hasil Belajar Siswa dalam Pembelajaran PKn. Jurnal Pendidikan dan Kebudayaan. Vol 19 (2). Hal: 315-330.

[14] Fortune, M. F., Spielman, M., \& Pangelinan, D. T. (2011). Students' Perceptions of Online or Face-to-Face Learning and Social Media in Hospitality, Recreation and Tourism. MERLOT Journal of Online Learning and Teaching, 7(1), 1-16.

[15] Roberts, T. S., \& McInnerney, J. M. (2007). Seven problems of online group learning (and their solutions). Educational Technology and Society. https://doi.org/10.1111/j.215169 52.1960.tb01699.x

[16] Adijaya, N., Santosa, L. P. (2018). Persepsi Mahasiswa dalam Pembelajaran Online. Wanastra. Vol. 10(2). Hal: 105-110

[17] Prastowo, A. (2012). Panduan Kreatif Membuat Bahan Ajar Inovatif. Yogyakarta: Diva Press 